\title{
MNIEJSZOŚĆ ŻYDOWSKA W KSIĘSTWIE BUŁGARII W LATACH 1879-1885. WYBRANE PROBLEMY
}

\author{
BARTEOMIEJ RUSIN
}

\begin{abstract}
Jewish minority in the Principality of Bulgaria 1879-1885. Selected problems).
The article describes the situation of the Jewish minority after establishing the Principality of Bulgaria in 1879 . The situation of the Jewish minority and other ethnic and religious groups in the country was heavily dependent on the authorities and different governments aiming at the achievement of the national ideals of Bulgaria - the creation of an ethically solid and territorially united state in the Balkans. These goals influenced the Bulgarian policy towards Jewish and other minorities in the country, especially between 1882-1883 and 1884-1886, when pro-Russian politicians run the government. The Jews in the Principality worked mostly as small merchants and craftsmen, so even though they were considered to be wealthy their situation did not differ from the situation of the Bulgarian population of the country. Generally, the minority was deprived of the possibility of achieving high official and administration posts, as well as high military ranks in the army, even after the participation of the Jews in the Serbo-Bulgarian war in 1885. The education and the level of development of the Jewish culture in the country were also very low. Jewish schools were financially subsidized by international organisations, especially the Alliance Israelite Universelle, but the local communities still lacked money for teachers and proper buildings. Jewish theatres and newspapers were also underfunded, that is why the first Jewish newspaper appeared in the country only in 1893. In conclusion, therefore, it seems that the situation of the Jews in the Principality of Bulgaria was not particularly bad, especially when we take into consideration the level of anti-Semitism in neighbouring Romania. The Jews were satisfied with the conditions of living in Bulgaria, and they supported the national goals of the country, such as the unification of the Principality with the province of Eastern Roumelia in 1885 .
\end{abstract}

Autor: Bartłomiej Rusin, Instytut Nauk Politycznych i Stosunków Międzynarodowych, Wydział Studiów Międzynarodowych i Politycznych, Uniwersytet Jagielloński, ul. Jabłonowskich 5, 31-114 Kraków, bartlomiej. rusin@gmail.com

Słowa kluczowe: Żydzi, Księstwo Bułgarii, mniejszości, syjonizm, ochotnicy w wojnie bułgarsko-serbskiej 1885 roku, konstytucja tyrnowska

Keywords: Jews, Principality of Bulgaria, minorities, Zionism, volunteers in Bulgaro-Serbian war of 1885, Tyrnovo constitution

Balcanica Posnaniensia. Acta et studia, XXII/2, Poznań 2015, Wydawnictwo Instytutu Historii UAM, pp. 37-54, ISBN 978-83-63047-88-7, ISSN 0239-4278. Polish text with a summary in English.

Sytuacja mniejszości zamieszkujących utworzone na mocy postanowień kongresu berlińskiego Księstwo Bułgarii była szczególna. Z jednej strony, ich położenie uwarunkowane było decyzjami wielkich mocarstw, które narzuciły młodemu państwu szereg zapisów dotyczących ochrony mniejszości w traktacie berlińskim (wolność wyznania i swobodnego praktykowania religii, zakaz dyskryminacji w życiu społecz- 
nym i politycznym ze względu na wyznanie) ${ }^{1}$, co następnie potwierdzono w uchwalonej 16 kwietnia 1879 roku konstytucji tyrnowskiej². Idealistyczne zapisy nowej ustawy zasadniczej pozostawały w sprzeczności z dążeniami narodowymi Bułgarów, którzy za swój główny cel upatrywali utworzenie zjednoczonego terytorialnie (ze wszystkich ziem historycznie uważanych za bułgarskie) i etnicznie państwa, gdzie dominującym elementem pozostawaliby prawosławni Słowianie. Proces tworzenia takiego państwa miał się rozpocząć jeszcze z początkiem wojny rosyjsko-tureckiej z lat $1877-1878^{3}$.

Za największe zagrożenie dla budowy wspólnej tożsamości narodowej uważano najliczniejszą w Księstwie mniejszość turecką (ponad 26\%), na czym zaważyła przede wszystkim prawie pięciowiekowa dominacja tej grupy etnicznej na ziemiach bułgarskich. Niechęć w stosunku do Żydów miała zdecydowanie mniejszy zasięg i była uwarunkowana pewnymi stereotypami utrwalonymi w rodzimej tradycji i kulturze. Niemniej, na zaostrzeniu stanowiska Bułgarów wobec tej grupy zaważył okres tuż przed odnowieniem państwa. Było to spowodowane denuncjowaniem przez niektórych Żydów do władz tureckich działaczy i żołnierzy bułgarskich w czasie konfliktu z lat 1877-1878, postrzeganego przez Bułgarów jako wojna „wyzwoleńcza”, co doprowadziło do wystąpień i bandyckich napaści na tę ludność w kilku mniejszych miastach, m.in. w Swisztowie, Kazanłyku i Eski-Zaara [dziś Stara Zagora] ${ }^{4}$. Na stosunek Bułgarów wobec Żydów wpływ wywarło również rozdzielenie ziem bułgarskich na kilka części, o czym zadecydowały wielkie mocarstwa w Berlinie. Powszechnie wierzono, że głównym odpowiedzialnym za niepomyślne dla Bułgarów decyzje był premier Wielkiej Brytanii Benjamin Disraeli (też Żyd), konsekwentnie sprzeciwiający się odtworzeniu bułgarskiej państwowości na Bałkanach w okresie kryzysu z lat 1875-1878. Ukuto wręcz czarną legendę brytyjskiego polityka, który porównywany był w Bułgarii ze średniowiecznym cesarzem bizantyjskim Bazylim II, zwanym „Bułgarobójcą"5.

W momencie uchwalenia konstytucji tyrnowskiej i stworzenia zrębów państwowości Księstwa mniejszość żydowska znajdowała się więc w trudnej sytuacji (podobnie jak inne mniejszości) i zmuszona była funkcjonować w rzeczywistości tworzonej przez bułgarską większość, która dążąc do realizacji swoich celów narodowych, przy

\footnotetext{
${ }^{1}$ Mówił o tym art. 5 traktatu berlińskiego. Postanowienia dotyczące Księstwa Bułgarii i Rumelii Wschodniej, autonomicznej prowincji pozostającej w granicach Imperium Osmańskiego, zawarto w artykułach 1-22 dokumentu. Zob. Documents diplomatiques. Affaires d'Orient. Congrès de Berlin 1878, Paris 1878 , s. 275-283.

2 B. Rusin, Konstytucja tyrnowska z 1879 roku-historia, ustrój, język, w: Historyczna i ponowoczesna tożsamość Stowian, red. J. Zatorska, A. Skoczylas, T. Ciesielski, Łódź 2012, s. 83-84. Wszystkie daty dzienne zostały podane według kalendarza gregoriańskiego.

${ }^{3}$ P. Üre, Immediate effects of the 1877-1878 Russo-Ottoman War on the Muslims of Bulgaria, "History Studies", 2013, nr 13, s. 153-154.

${ }^{4}$ B. Rusin, Pogromy Żydów na ziemiach bułgarskich Imperium Osmańskiego w czasie wojny rosyjsko-tureckiej 1877-1878, „Studia z Dziejów Rosji i Europy Środkowo-Wschodniej” [w druku].

5 Р. Генов, Дизраели, еврейството и антисемитизъм в България, http://dialogueeurope.org/uploads/JewsCol/Panel101.pdf, s. 25 [dostęp: 10.01.2015].
} 
jednoczesnym braku tradycji demokratycznych i poszanowania prawa, często nie respektowała postanowień własnej ustawy zasadniczej. Ramy czasowe artykułu obejmują okres między uchwaleniem konstytucji tyrnowskiej 16 kwietnia 1879 roku, wyznaczającej podstawy nowego ustroju, a zjednoczeniem Księstwa Bułgarii z Rumelią Wschodnią 18 września 1885 roku i będącą jego konsekwencją wojną serbsko-bułgarską.

Trudno określić, ilu Żydów zamieszkiwało ziemie bułgarskie bezpośrednio przed wojną z lat 1877-1878, ze względu na niepełne i często sprzeczne dane statystyczne. Historyk bułgarski Dawid Koen cytuje różne źródła na ten temat, wedle których liczba Żydów wahała się między 10 a 20 tys. osób. Z kolei bezpośrednio po wojnie, wedle danych pochodzących ze spisu ludności przeprowadzonego przez tymczasową administrację rosyjską, ziemie bułgarskie (bez podziału na Księstwo Bułgarii i Rumelię Wschodnią) zamieszkiwało 14263 Żydów. Spisy przeprowadzone w 1880 roku osobno dla obu tych prowincji wskazują na nieco wyższy odsetek Żydów w porównaniu $\mathrm{z}$ rejestrem rosyjskim. Według tych danych terytorium Księstwa Bułgarii zamieszkiwało 14342 osób pochodzenia żydowskiego (7102 mężczyzn i 7240 kobiet), natomiast w Rumelii Wschodniej mniejszość ta liczyła 4177 osób $^{6}$. Z kolei dane ze spisu przeprowadzonego w 1887 roku (czyli już po zjednoczeniu państwa) wskazują, że Bułgarię zamieszkiwało 24352 Żydów, co stanowiło 0,77\% całej populacji młodego państwa ${ }^{7}$.

Żydzi w Księstwie zamieszkiwali przede wszystkim miasta, a największa ich część skupiona była w stolicy kraju. Według danych z 1880 roku w Sofii mieszkały 5132 osoby narodowości żydowskiej, stanowiąc dość znaczny odsetek całej populacji miasta, które jeszcze w 1887 roku liczyło zaledwie 31 tys. mieszkańców. Tabela na s. 40 przedstawia okręgi, w których mniejszość żydowska liczyła co najmniej 100 osób.

W momencie utworzenia Księstwa Bułgarii Żydzi żyli w niepowiązanych ze sobą gminach, spotykając się w zasadzie jedynie w celu wyboru nowego rabina. Do takich spotkań doszło w 1884, 1887 i 1889 roku, jednak w każdym z nich brała udział jedynie część społeczności żydowskiej w tym kraju. Inicjatorem pierwszego kongresu gmin żydowskich w Księstwie Bułgarii była społeczność Żydów sofijskich. Podczas obrad dokonano wyboru nowego reprezentanta wszystkich gmin w kraju, którym został Presjaduczo Tadżer. Kongres podjął również decyzję o konieczności zmiany na stanowisku głównego rabina, na osobę młodą i energiczną, która zastąpiłaby będącego w podeszłym wieku Gabriela Almoznino, delegata mniejszości żydowskiej do Zgromadzenia Konstytucyjnego w Tyrnowie w 1879 roku. Na jego wniosek powoła-

\footnotetext{
6 Д. Коен, Българските евреи по време на Освобождението от турско владичество, w: Idem, Евреите в България (1878-1949). Студии, София 2008, s. 14, 19-21. Tekst pierwotnie opublikowano w: „Годишник на Обществено-културно-просветна организация на евреите в България” [Dalej jako: „Годишник ОКПОЕ”], 1969, t. 4, s. 169-183. W dalszej części cytowane jest wyłącznie nowe wydanie tekstu Koena.

7 А. Калев, Данни относно демографското положение на българските евреи (1887-1940), „Годишник ОКПОЕ”, 1981, t. 16, s. 100.
} 
Mniejszość żydowska w Bułgarii

\begin{tabular}{|l|c|c|c|}
\hline \multicolumn{1}{|c|}{ Okręg } & $\begin{array}{c}\text { Żydzi deklarujący } \\
\text { judaizm jako swoje } \\
\text { wyznanie }\end{array}$ & $\begin{array}{c}\text { Odsetek Żydów w całej } \\
\text { populacji okręgu (w \%) }\end{array}$ & $\begin{array}{c}\text { Osoby deklarujące ladino } \\
\text { jako język ojczysty }\end{array}$ \\
\hline Berkowica & 380 & 0,6 & 383 \\
Kjustendił & 1818 & 1,3 & 1812 \\
Łom & 363 & 0,9 & 363 \\
Plewen & 429 & 0,4 & 420 \\
Prowadija & 296 & 0,5 & 293 \\
Razgrad & 247 & 0,2 & 234 \\
Ruse & 2028 & 1,6 & 1963 \\
Silistra & 322 & 0,3 & 318 \\
Sofia & 5132 & 3,2 & 5001 \\
Szumen & 793 & 0,7 & 777 \\
Warna & 719 & 0,7 & 680 \\
Widyń & 1520 & 1,5 & 1483 \\
Wraca & 203 & 0,3 & 203 \\
\hline
\end{tabular}

Źródło: Opracowanie własne na podstawie: Д. Коен, Българските евреи по време..., s. $20^{8}$.

ny został do życia centralny konsystorz, mający pełnić funkcję ciała pomocniczego głównego rabina i dbać o interesy wspólnoty. Po Almoznino zwierzchnikiem religijnym w Księstwie wybrano dra Szimona Dankowicza, który jednak po niedługim czasie utracił stanowisko na rzecz Jakira Presjaduczo ${ }^{9}$.

Pełnienie funkcji głównego rabina związane było z szeregiem obowiązków, przede wszystkim o charakterze religijnym. To on wyznaczał i był bezpośrednim zwierzchnikiem wszystkich rabinów w stolicy kraju i na prowincji. Zdarzały się jednak przypadki, gdy w wybór nowego rabina ingerowały czynniki rządowe, nakazujące elekcję „odpowiedniej” osoby do tej funkcji. Poza tym miał on dbać również o będące w posiadaniu wspólnoty synagogi, jak również zwrot nieruchomości żydowskich, zapewniających dochody. Dodatkowe obowiązki głównego rabina pojawiły się w połowie lat 80 . XIX wieku, kiedy na rodzimym rynku wydawniczym ukazał się szereg broszur o charakterze antysemickim, stanowiących w znakomitej większości przekłady z języków obcych, m.in. z niemieckiego. Protest swój Almoznino skie-

\footnotetext{
${ }^{8}$ Różnice między populacją Żydów w niektórych miastach, a liczbą osób posługujących się ladino (używanym przez Żydów sefardyjskich, którzy wyemigrowali z Półwyspu Iberyjskiego pod koniec $\mathrm{XV}$ wieku) wynika z faktu, że w Bułgarii bycie Żydem było równoznaczne z wyznaniem mojżeszowym. Osoby będące etnicznymi Żydami, ale nie deklarujące wyznania mojżeszowego jako własnego były wykluczane poza wspólnotę. Niemniej, grupa taka istniała w Bułgarii, ich liczba była jednak niewielka. Według spisu z 1934 roku etnicznymi Żydami deklarującymi inne niż judaizm wyznanie było w sumie 167 osób. Zob. А. Калев,op. cit., s. 100.

9 Д. Коен, Сефардските общиини в България (1878-1944 г.), w: Idem, op. cit., s. 73-74.
} 
rował jednak jedynie do głównego organu prasowego opozycji, podejrzewając, że w kręgach rządowych znajdowały się osoby wspierające nieoficjalnie tego typu wydawnictwa oraz ludzie mieszkający długi czas w sąsiedniej Rumunii lub Rosji, gdzie przesiąkli ideami o charakterze rasistowskim ${ }^{10}$.

Zasadniczo, postanowienia kongresu berlińskiego, rozszerzone następnie i dookreślone w konstytucji tyrnowskiej zapewniały wszystkim osobom przebywającym na terytorium Księstwa wolność wyznania. Jedynym warunkiem było poszanowanie dla panującego porządku społecznego i politycznego, bez względu na własną religię (art. 41 konstytucji). W praktyce jednak dbałość władz przede wszystkim o zachowanie prawosławnego charakteru państwa skłaniała je do ograniczania tych praw, jak choćby w przypadku wspomnianego wyżej rabina Dankowicza, który został odwołany ze stanowiska ze względu na nieuregulowaną kwestię swojego obywatelstwa ${ }^{11}$. Na okresowe zmiany kursu wobec Żydów wpływ wywierały również niektóre gabinety obejmujące władzę w państwie, jak było choćby w przypadku rządu Petko Karawełowa (1884-1886), kiedy to pensje rabinów zostały zmniejszone o $25 \%{ }^{12}$.

Zgodnie z postanowieniami ustawy zasadniczej obywatele pochodzenia żydowskiego, podobnie jak przedstawiciele innych mniejszości, mogli swobodnie korzystać z czynnego i biernego prawa wyborczego (art. 86) ${ }^{13}$. W praktyce jednak Żydzi od samego początku napotykali na rozmaite problemy w tej sferze. Część przedstawicieli tej mniejszości nie wzięła udziału w wyborach parlamentarnych już w listopadzie 1878 roku, ze względu na ciągle niezakończone procesy migracyjne po wojnie rosyjsko-tureckiej. Z kolei we wrześniu 1879 roku warunkiem uczestnictwa w wyborach był co najmniej sześciomiesięczny okres przebywania na terytorium Księstwa Bułgarii, co uderzyło także w inne mniejszości, przede wszystkim w najliczniejszych w państwie Turków. Nie bez znaczenia były również różne nadużycia związane z organizacją i samym przeprowadzaniem wyborów (m.in. głosowanie jawne, rozdawanie wypełnionych kart do głosowania, kupowanie głosów), co było zjawiskiem normalnym w państwie, które dopiero uczyło się podstaw demokratycznego systemu wyborczego. Niewątpliwą słabością mniejszości był także brak własnych partii politycznych. Zazwyczaj byli oni włączani do głównych ugrupowań walczących o władzę, stając się narzędziem w rękach partyjnych centrali, które dodatkowo pacyfikowały ich ewentualną aktywność poprzez rozczłonkowanie przedstawicieli mniejszości

10 Ж. Назърска, Българската държава и нейните малцинства 1879-1885, София 1999 , s. 31-33.

11 Powodem odwołania Dankowicza był fakt, że nie był obywatelem Bułgarii. Władze państwowe pilnowały bowiem, aby osoby pełniące wysokie funkcje w instytucjach należących do mniejszości ustosunkowały się do kwestii swojego obywatelstwa. Zob. Е. Ешкенази, Освобождението на България и българските евреи (Създаването на равинския институт), „Годишник ОКПОЕ”, 1979, t. 14, s. 27.

12 Ж. Назърска, Българската държава и нейните малцинства..., s. 30.

13 W przypadku czynnego prawa wyborczego konieczne było ukończenie 21 lat, natomiast w przypadku biernego prawa wyborczego obowiązywał cenzus wieku powyżej 30 lat oraz obowiązek piśmienności kandydata. Zob. B. Rusin, Prawa, wolności i obowiązi człowieka i obywatela w świetle konstytucji tyrnowskiej z 1879 r., „Meritum. Rocznik Koła Naukowego Historyków-Doktorantów UWM w Olsztynie", 2012, t. IV, s. 100. 
między różne, niejednokrotnie skłócone ze sobą partie. Dotyczyło to przede wszystkim najliczniejszej mniejszości tureckiej. Jeśli idzie natomiast o Żydów, to zazwyczaj wspierali oni w wyborach kandydatów partii konserwatywnej. Wyjątkiem były wybory do pierwszego zwykłego Zgromadzenia Narodowego w jesieni 1879 roku, kiedy to Żyd sofijski uzyskał 43\% głosów (dwa razy więcej niż liczyła mniejszość żydowska w tym mieście), natomiast z okręgu miasta Ruse mandat uzyskało trzech przedstawicieli tej grupy. Żaden z nich nie znalazł się jednak w parlamencie, uznano bowiem, że Żydzi nie są grupą polityczną, tylko etniczną, w związku z czym odmówiono podpisania protokołów wyborczych. Ostatecznie, w omawianym okresie żaden przedstawiciel mniejszości żydowskiej nie zasiadł w parlamencie, co nie do końca odpowiadało strukturze etnicznej i wyznaniowej państwa. Partie wybierały też zazwyczaj słabiej wykształconych przedstawicieli wszystkich mniejszości, gdyż łatwiej było nimi manipulować, a nawet ich głosami przeprowadzać projekty ustaw ograniczające ich prawa, choćby w kwestii posiadanych majątków ziemskich, edukacji czy ordynacji wyborczej $^{14}$. Jedynym przedstawicielem rodzimej mniejszości żydowskiej, który został wybrany na członka parlamentu w 1894 roku był Petyr Gabe (1857-1927), ojciec sławnej poetki Dory Gabe (1888-1983). Jego mandat został jednak unieważniony podczas pierwszej sesji nowo wybranego zgromadzenia, a powodem było rosyjskie pochodzenie deputowanego oraz rzekomy brak obywatelstwa bułgarskiego. Nie pomógł również list protestacyjny wysłany przez grupę wyborców z okręgu Bałczik, $\mathrm{z}$ którego Petyr Gabe ubiegał się o mandat posła ${ }^{15}$.

Podobnie, Żydzi nie zajmowali żadnych wyższych stanowisk w bułgarskich ministerstwach, a ich rola ograniczała się do pracy jako drobni urzędnicy niższych szczebli administracji. Tytułem przykładu można wskazać Ministerstwo Sprawiedliwości, gdzie początkowo Żydzi nie byli w ogóle reprezentowani, ze względu na niespełnianie określonych warunków, w tym przede wszystkim brak odpowiedniego wykształcenia i doświadczenia. Pierwsi przedstawiciele tej i innych mniejszości (przede wszystkim Turków) zostali zatrudnieni w tym resorcie dopiero na początku 1880 roku, obejmując specjalnie utworzoną dla nich funkcję pomocników naczelników w sądach, w związku z napiętą sytuacją w niektórych regionach kraju, gdzie dochodziło do licznych rozbojów lub byli oni poddawani naciskowi zewnętrznemu ze strony Porty osmańskiej. Dane za ten sam rok wskazują, że spośród 300 sędziów pracujących w sądach bułgarskich Żydzi stanowili 1\% wszystkich zatrudnionych, co nie do końca odpowiadało ich liczebności w kraju. Niemniej, nie należy uznawać tego za dyskryminację, bowiem w Księstwie Bułgarii nie obowiązywały odgórnie narzucone kwoty, jak było w sąsiedniej Rumelii ${ }^{16}$. Wyjątkiem były tu Ministerstwo Wojny oraz Ministerstwo Spraw Zagranicznych, gdzie w omawianym okresie nie pracowa-

14 Ж. Назърска, Етническите и религиозните малиинства в българския парламент (18791885), „Исторически преглед”, 1999, nr 1-2, s. 3-22.

15 T. Nedkov, Peter Gabe 1857-1927. 110 Years Since His Settlement in Bulgaria, "Annual”, 1995, t. 28, s. 226-231.

16 Ж. Назърска, Българската държава и нейните малицнства..., s. 189-192. 
ła żadna osoba pochodzenia żydowskiego. Najwyższym stanowiskiem piastowanym przez Żyda w Bułgarii po 1878 roku była funkcja ministra sprawiedliwości, sprawowana przez Josifa Fadenchefta w 1918 roku $^{17}$. Z kolei we władzach miejskich w Sofii, gdzie mniejszość ta stanowiła znaczny odsetek całej populacji, utrwaliła się praktyka udziału Żydów w roli gminnych doradców. Byli nimi między innymi Mordechaj Chaim, Awram Dawid i Solomon Lewi ${ }^{18}$.

Jak wspomniano wyżej, Żydzi skupiali się przede wszystkim w największych miastach Księstwa, stąd też podstawą ich utrzymania były zawody typowo miejskie. Większość z nich zajmowała się drobnym handlem lub prowadziła zakłady rzemieślnicze (uważano ich za dobrych szewców, krawców, producentów tekstyliów oraz rymarzy), jednak były to tylko resztki dobrobytu lokalnej wspólnoty, która w czasach świetności Imperium Osmańskiego stanowiła grupę doradców dworu i wpływowych finansistów. Tytułem przykładu można wskazać wspólnotę żydowską z okręgu starozagorskiego, gdzie Żydzi trudnili się przede wszystkim blacharstwem i cukiernictwem, tylko niewielu z nich było kupcami, z czego część posiadała obywatelstwo tureckie $^{19}$. W Sofii z kolei Żydzi zajmowali się głównie handlem, co było związane z faktem, że w mieście tym brakowało ciągle dużych fabryk i przedsiębiorstw produkcyjnych, zlokalizowanych w innych częściach młodego państwa. Stąd też stolica kraju, pozbawiona znaczniejszych kontaktów handlowych z zagranicą, wytwarzała początkowo dobra głównie na potrzeby swoje i okolicznych miejscowości. W takich warunkach biznesy kierowane przez przedstawicieli mniejszości żydowskiej nie mogły się rozwijać, stąd w omawianym okresie ich dochody nie różniły się zbytnio od zarobków Bułgarów ${ }^{20}$. Niemniej, zdominowanie tej dziedziny gospodarki w stolicy przez przedstawicieli mniejszości żydowskiej miało budzić ich niezadowolenie, co skutkowało ograniczeniem kontaktów handlowych między obiema grupami oraz niechęcią do chrześcijan, którzy decydowali się jednak zawierać transakcje z Żydami ${ }^{21}$.

Z trudnościami Żydzi spotykali się także ze strony rozmaitych organów państwowych. Motywowano je niekiedy koniecznością zwalczania spekulacji żydowskiej, jak było chociażby w okresie istnienia gabinetu rosyjskiego generała Leonida Sobolewa

${ }^{17}$ Fadencheft pełnił swoją funkcję w rządzie Aleksandra Malinowa, sformowany w lecie 1918 i działającym do listopada tego samego roku. Zob. Т. Ташев, Министрите на България 1879-1999, София 1999, s. 73-74.

18 П. Неделева, Място и роля на еврейската общност в българските земи (от османско владичество до 30-те години на ХХ в.), „Юридическо списание на НБУ”, 2013, nr 2, s. 49.

19 А. Илиев, Старозагорский окръг в народоикономическо отношение, Стара Загора 1885. Cyt. za: Евреите по българските земи. Анотирана библиография, съст. Ж. Ескенази, А. Криспин, София 2002, s. 236.

${ }^{20}$ Х. Ботушаров, Софийските евреи през 1878-1885 г., „Годишник ОКПОЕ”, 1988, t. 23, S. 105 .

21 J. Samuelson, Bulgaria. Past And Present, London 1888, s. 124-125. Inny z kolei autor, podróżujący po ziemiach Księstwa i Rumelii Wschodniej w omawianym okresie, pisał, że Bułgarzy nie obawiali się konkurencji ze strony Żydów sefardyjskich mieszkających na tych terenach, ale przede wszystkim tych przybyłych z Rumunii i Rosji. Zob. J. Erdic, En Bulgarie et en Roumélie, May-Juin 1884, Paris 1884, s. 41. 
w latach 1882-1883 (czyli w czasie obowiązywania tzw. reżimu pełnomocnictw22). Urzędujący wtedy kolejni ministrowie finansów Grigor Naczowicz i Todor Burmow nakazali odrzucić wszystkie zgłaszane przez Żydów patenty oraz utrudnić im zakup karczm oraz pomieszczeń na sklepy i zakłady rzemieślnicze. Ponadto, w latach 18811883 Żydom ograniczano możliwości w zakresie powiększania posiadanej własności oraz osiedlania się, szczególnie w miastach naddunajskich i czarnomorskich. Podobną politykę kontynuował gabinet Petko Karawełowa w latach 1884-1886. W 1884 roku w Dupnicy doszło do zabicia jednego z miejscowych Żydów i okradzenia jego domu. O przestępstwo zostali jednak oskarżeni przedstawiciele tej mniejszości. Poza tym, stojące na czele miasta władze nie reagowały na prześladowania tej grupy przez pochodzących z ziem macedońskich uchodźców, licząc na stopniową emigrację Żydów z miasta. Utrudnieniu ich funkcjonowania w Dupnicy służyło też przeniesienie dnia, w którym odbywał się targ z wtorku na sobotę, czyli na dzień święty dla wyznawców judaizmu. Niemniej, to Turcy a nie inne mniejszości znajdowali się w centrum polityki fiskalnej Księstwa w omawianym okresie ${ }^{23}$.

Wiele do życzenia pozostawiał również rozwój kulturalny i poziom wykształcenia Żydów w momencie odnowienia państwowości bułgarskiej. Do momentu utworzenia Księstwa Bułgarii podstawą żydowskiej edukacji były szkoły talmudyczne, funkcjonujące przy synagogach. W związku z brakiem wsparcia finansowego ze strony państwa utrzymanie tych ośrodków pozostawało na barkach lokalnych wspólnot, które ze względu na własną trudną sytuację materialną często nie radziły sobie z opłaceniem kadry oraz zapewnieniem odpowiedniego poziomu nauczania. Dlatego też w szkołach tych (poza nauką języka bułgarskiego, który był subsydiowany przez państwo) programy nauczania pozostały przestarzałe, a edukacja młodych ludzi opierała się przede wszystkim na czytaniu Talmudu, nauce pisania i religii oraz śpiewie ${ }^{24}$.

Sytuacja zaczęła zmieniać się powoli jeszcze od początku lat 70. XIX wieku, kiedy na ziemiach bułgarskich pojawiły się pierwsze ośrodki finansowane przez Alliance Israélite Universelle, organizację założoną w Paryżu w 1860 roku przez Adolphe'a Crémieux, której celem był rozwój i stopniowa okcydentalizacja wspólnoty żydowskiej żyjącej w świecie ${ }^{25}$. Pierwsze takie szkoły założono w Szumenie (1870), Samokowie (1874) i Widyniu (w 1876 roku). W 1879 Alliance przejął szkołę męską w Ruse (w 1885 także szkołę żeńską w tym mieście) oraz otworzył inny ośrodek w Sofii, kierowany początkowo przez Josepha Benchimola. Wszystkie szkoły finanso-

22 Reżim pełnomocnictw obowiązywał w Bułgarii od obalenia przez monarchę rządu Petko Karawełowa w kwietniu 1881 roku do grudnia 1883 roku. W tym czasie doszło do zawieszenia konstytucji tyrnowskiej i ograniczenia roli parlamentu. Książę Aleksander Battenberg sprawował swój urząd poprzez osobiście powoływane rządy i Radę Państwa. Zob. Й. Гешева, Режимът на пълномощията своеобразна форма на управление на държавата (1881-1883 2.), w: Eadem, Консерваторите, партията, личностите и изграждане на българската държсава 1879-1886 г., София 2013, s. 231-247.

23 Ж. Назърска, Българската държава и нейните малиинства ..., s. 64-65, 77-78, 116.

24 Ibidem, s. 87-88.

25 J. Bigart, The Alliance Israélite Universelle, “American Jewish Year Book”, 1901, nr 2, s. 45-66. 
wane przez AIU borykały się początkowo z problemem braku odpowiedniej kadry, co skłoniło dyrekcje do zatrudniania jako nauczycieli także miejscowych rabinów. Z biegiem czasu starano się odchodzić od tej praktyki, jako że organizacja stawiała sobie za cel zapewnienie Żydom świeckiej edukacji. Zwierzchnikiem i nauczycielem w szkołach prowadzonych przez organizację był również wywodzący się z Bułgarii Gabriel Arié, który po zakończeniu edukacji w Paryżu w 1881 roku objął posadę dyrektora jednej z placówek w Konstantynopolu, a następnie w Sofii w 1887 roku. W momencie przejmowania przez niego kierownictwa szkoła w stolicy Bułgarii wznawiała swoją działalność po dwuletniej przerwie ${ }^{26}$.

Językiem nauczania w szkołach AIU miał być francuski, co przyjęto bez sprzeciwów właściwie we wszystkich krajach, gdzie znajdowały się placówki finansowane przez organizację. W tym języku miała być prowadzona większość przedmiotów nauczanych w szkole, w tym arytmetyka, geografia, historia, przedmioty ścisłe i przyrodnicze, kaligrafia, śpiew oraz gimnastyka. Jedynym wyjątkiem od tej reguły stała się Bułgaria, gdzie po przyjęciu w 1885 roku specjalnej ustawy (na podstawie projektu Konstantina Jirečka) wprowadzono obowiązek nauczania języka bułgarskiego i religii prawosławnej. Dodatkowo niektóre placówki edukacyjne zostały poddane ścisłej kontroli ze strony Ministerstwa Oświecenia Narodowego, które nadzorowało proces nauczania języka bułgarskiego, a także żądało, aby nauczyciele byli obywatelami państwa. W przypadku szkół prowadzonych przez AIU skomplikowało to znacznie proces naboru odpowiednio wykwalifikowanej kadry, której i tak brakowało ${ }^{27}$.

AIU wspierało również uczniów, którzy po zakończeniu edukacji w ośrodkach prowadzonych przez organizację decydowali się na kontynuowanie nauki w szkołach bułgarskich, szczególnie jeśli deklarowali gotowość objęcia w przyszłości posady nauczyciela. W tym kontekście problemem pozostawały niekiedy poglądy samych uczniów, bowiem władze organizacji oczekiwały od nich wierności ideom głoszonym przez AIU, nie zgadzając się na propagowanie przez nich teorii syjonistycznych. Ze względu właśnie na tę kwestię zdarzały się przypadki odmowy udzielenia stypendium przez dyrektora Alliance, urzędującego w Sofii ${ }^{28}$.

Alliance założył w Bułgarii w sumie 14 szkół, w których nauczało 98 nauczycieli. W późniejszych latach szkoły żydowskie w Bułgarii finansowała również organizacja Hilfsverein der Deutschen Juden, założona w 1901 roku. Jeszcze w tym samym roku w szkołach wspieranych przez obydwie organizacje uczyło się 3870 uczniów $^{29}$.

Niewielka grupa bogatych Żydów decydowała się też wysyłać dzieci do szkół poza granicami kraju. Tylko w 1883 roku zapisali oni do szkół francuskich 49 chłopców i 8 dziewczynek (liczba ta dotyczy Żydów z Księstwa Bułgarii i Rumelii Wschod-

26 A Sephardi life in Southeastern Europe. The autobiography and journal of Gabriel Arié, 1863 1939, red. E. Benbassa, A. Rodrigue, Seattle-London 1998, s. 73, 85.

27 Ж. Назърска, Българската държава и нейните малцинства..., s. 81; D. Omer, Le français, l'allemand, l'anglais: l'impossible alliance? L'example du réseau scolaire de l'AIU (1860-1913), http:// hal.univ-nantes.fr/hal-01112097/document, s. 3-4 [dostęp: 10.02.2015].

28 Н. Цвятков, Просветното дело сред българските евреи ..., s. 117.

29 N. M. Gelber, Jewish life in Bulgaria, ,Jewish Social Studies”, 1946, t. 8, nr 2, s. 115. 
niej) ${ }^{30}$. Niewielka część decydowała się natomiast kontynuować edukację, podejmując studia na Uniwersytecie Sofijskim (utworzonym w 1888 roku) lub na uczelniach za granicą. W okresie 1878-1915 około 20 z nich obroniło doktoraty (głównie z dziedziny prawa i medycyny) w zagranicznych ośrodkach naukowych ${ }^{31}$.

Odnowienie państwowości bułgarskiej w 1878 roku stanowiło również nowy impuls w rozwoju kultury żydowskiej, która wcześniej, wraz z powolną atrofią osmańskiej Turcji, mocno podupadła. Na ziemiach bułgarskich zaczęły powstawać nowe instytucje i ośrodki kulturalne, samorzutnie tworzyły się nieprofesjonalne chóry (te tworzone były przede wszystkim przy synagogach) i trupy teatralne, niemniej to na ziemiach Rumelii Wschodniej powstał pierwszy amatorski teatr żydowski, zorganizowany w Płowdiwie w 1882 roku. Było to swoiste novum jeśli chodzi o obecność Żydów w tej dziedzinie, ponieważ wcześniej znani byli oni głównie dzięki przedstawieniom lalkowego teatru cieni, popularnych na ziemiach tureckich od XVII wieku ${ }^{32}$. Pierwszą sztuką wystawioną na deskach nowego teatru była „Estera”, autorstwa dramaturga-amatora Habriego Rachamima Pijadego. Duże zainteresowanie, jakim cieszyło się przedstawienie, skłoniło kolejnych twórców i aktorów do wystawiania na deskach płowdiwskiego teatru kolejnych sztuk inspirowanych tematyką biblijną. Na powstanie pierwszego teatru żydowskiego na północ od gór Starej Płaniny trzeba było jednak czekać jeszcze kilkanaście lat, kiedy w 1890 roku w Ruse zaczęto wystawiać najpierw przekłady sztuk zachodnich, a później również autorskie teksty dramaturga Josifa Awrama Papo. Tutaj też za inspirację posłużyły przede wszystkim utwory poświęcone tematyce religijnej ${ }^{33}$. Teatr żydowski w Bułgarii, nie tylko w latach 1879-1885, ale jeszcze wiele lat potem, tworzony był przede wszystkim przez sefardyjski odłam tej mniejszości. Pierwsi Żydzi aszkenazyjscy (których liczba w Bułgarii nigdy nie przekroczyła 10\% tej grupy) pojawili się na deskach teatrów dopiero w latach 30 . XX wieku ${ }^{34}$.

Twórcy konstytucji tyrnowskiej stworzyli warunki do swobodnego rozwoju prasy i wydawnictw, poprzez wprowadzenie do tekstu zapisu mówiącego o zachowaniu wolności druku i zakazie cenzury (art. 79). Pomimo braku ograniczeń pierwsza gazeta żydowska, nosząca tytuł „El Trezoro”, pojawiła się w Bułgarii dopiero w 1893 roku. Wydawano ją w ladino, dialekcie hiszpańskojęzycznych Żydów, powstałym po wygnaniu tej grupy z Półwyspu Iberyjskiego pod koniec XV wieku. We wcześniejszych latach Żydzi korzystali z prasy wydawanej w Konstantynopolu, Bukareszcie,

30 Н. Цвятков, Просветното дело сред българските евреи в края на ХІХ и началото на ХХ век, „Годишник ОКПОЕ”, 1980, t. 15, s. 116.

31 П. Неделева, ор. cit., s. 51.

${ }^{32} \mathrm{~W}$ organizowaniu tego rodzaju przedstawień specjalizowali się także przedstawiciele innych mniejszości w Imperium Osmańskim, przede wszystkim Cyganie, Ormianie i Grecy. Zob. W. Puchner, The Theatre in South-East Europe in the Wake of Nationalism, w: Tendances actuelles de la littérature compareé dans le Sud-est de l'Europe, red. A. Tabaki, Athènes 2007, s. 82.

33 Р. Манафова, Просветно и културно приобщаване на българските евреи от освобождението до първата световна война, w: Проучвания за еврейското население в българските земи XVХХ век, София 1980, s. 66-67.

${ }^{34}$ A. Fabrikant, The Ashkenazic Presence in Bulgaria, Part III. The Contribution of The Ashkenazim to The General Life of The Country, "Annual”, 1995, t. 28, s. 105-106. 
Adrianopolu, Salonikach i Belgradzie. Ogółem w latach 1878-1915 na rodzimym rynku wydawniczym wychodziło około 58 gazet i periodyków żydowskich, w tym 32 syjonistyczne, 21 antysyjonistycznych, 11 o charakterze kulturalno-oświatowym oraz trzy socjalistyczne. Osiem z nich było wydawanych po bułgarsku, reszta w ladino, w języku francuskim lub hebrajskim. Zdarzały się również tytuły wydawane w kilku językach, skierowane nie tylko do mniejszości, ale mające również informować samych Bułgarów o życiu lokalnej wspólnoty żydowskiej oraz toczących się wśród nich dyskusji o charakterze światopoglądowym. Ten ostatni aspekt był szczególnie ważny dla autorów propagujących idee syjonistyczne ${ }^{35}$. Problemem w wydawaniu żydowskiej prasy był przede wszystkim brak własnej drukarni, która została otwarta dopiero w 1893 roku, czyli dokładnie w momencie, kiedy pojawiła się na rodzimym rynku pierwsza gazeta żydowska. Podobnie było z drukowaniem książek. Pierwszą książkę (w ladino) autora żydowskiego Josifa Benreja wydrukowano jeszcze w Konstantynopolu w 1879 roku $^{36}$.

Autor nie dotarł do żadnych materiałów dotyczących historii sportu i w ogóle roli aktywności fizycznej wśród mniejszości żydowskiej w Bułgarii w interesującym nas okresie. Wiadomo natomiast, że pierwsze żydowskie towarzystwa gimnastyczne powstały już pod koniec XIX wieku, najpierw w Płowdiwie i Pazardżiku, później również w innych miastach. Pierwszy zjazd sportowców żydowskich z całego kraju miał miejsce w 1911 roku $^{37}$.

Bardzo skąpe są również dane dotyczące udziału Żydów w wojnie rosyjsko-tureckiej 1877-1878. Wiadomo na pewno, że Żydzi walczyli w oddziałach tzw. bułgarskiego pospolitego ruszenia, ochotniczych formacji sformowanych przy armii rosyjskiej. W tym kontekście najczęściej przywołuje się nazwiska Mojżesza Kalewa z Płowdiwu oraz Leona Krudowa z Samokowa. Były również przypadki Żydów służących w armii rosyjskiej, którzy decydowali się osiąść w Bułgarii po zakończeniu konfliktu ${ }^{38}$.

$\mathrm{Na}$ mocy postanowień konstytucji tyrnowskiej wprowadzony został obowiązek powszechnej służby wojskowej, obejmując swoim zasięgiem także mniejszości. Jeszcze w czasie obrad konstytuanty rabin sofijski Gabriel Almoznino, razem z deputowanymi greckimi i tureckimi, wręczył przewodniczącemu obrad prośbę o odroczenie tego obowiązku na okres pięciu lat, powołując się na fakt zwolnienia ludności nietureckiej od służby wojskowej w Imperium Osmańskim. Wniosek ten nie został nawet rozpatrzony. Postanowienia nowej ustawy zasadniczej zostały następnie potwierdzone w kolejnych dokumentach dotyczących służby wojskowej (z sierpnia 1879 i listopada 1880 roku), z których zwolnieni byli wyłącznie Żydzi posiadający paszport innego państwa. Co ciekawe, niektórzy Żydzi, o odróżnieniu od innych

35 Р. Манафова, op. cit., s. 61-62, 68-69.

36 П. Неделева, ор. cit., s. 51.

37 А. Кьосо, „Макаби” и еврейският спорт в България, „Вестник на вестниците”, 5 април 1936, бр. 50, s. 30. Суt. za: Евреите по българските земи..., s. 374.

38 П. Неделева, op. cit., s. 45. Tak było w przypadku Julija Ezereka, który ożenił się z Bułgarką i osiadł w Kazanłyku po zakończeniu wojny. Zob. И. Шипчанов, Съединението на България през 1885 г. и българските евреи, „Годишник ОКПОЕ”, 1985, t. 20, s. 48. 
mniejszości żyjących w Księstwie, sami zgłaszali gotowość podjęcia służby w tworzonej armii. Tylko w samym 1879 roku do wojska zgłosiło się około 200 Żydów. W kolejnych latach w niektórych miastach, np. w Warnie, Ruse czy Szumen dawało się zaobserwować zależność między wielkością populacji Żydów w całym państwie a liczbą poborowych pochodzących z tej niewielkiej społeczności. Sytuacja uległa zmianie w okresie funkcjonowania rządu Petko Karawełowa, który swoimi działaniami o charakterze antyżydowskim wywołał znaczący spadek liczby przedstawicieli tej grupy w armii bułgarskiej. Spośród wszystkich powołanych w tym okresie Żydów, do swoich jednostek zgłosiło się zaledwie $32 \%$ z nich ${ }^{39}$.

Kolejnym problemem, z jakim zetknęli się Żydzi służący w armii bułgarskiej, był brak zabezpieczenia ich wolności religijnych, wynikających z zapisów konstytucji tyrnowskiej. Dzięki naciskowi mocarstw zachodnich i Porty osmańskiej kwestię tę udało się rozwiązać na początku 1880 roku, kiedy to Żydom i Turkom na mocy specjalnego dokumentu przyznano prawo do zwolnienia z obowiązków służbowych w okresach świątecznych. Prócz wolnych sobót Żydzi otrzymali także prawo świętowania siedmiu uroczystości religijnych w ciągu roku, które mogły trwać maksymalnie 33 dni. Było to kolejne po wydanym rok wcześniej rozkazie, na mocy którego jedzenie dla żołnierzy żydowskich miało być przygotowywane oddzielnie, z zachowaniem wszystkich nakazów religijnych właściwych dla judaizmu ${ }^{40}$.

Pomimo gotowości Żydów do wstępowania do armii w pierwszym okresie po wyzwoleniu, nie mieli oni możliwości zrobienia kariery wojskowej. W tym zakresie funkcjonowały pewne reguły wewnętrzne i poufne okólniki, których stosowanie zależało od aktualnie panującego klimatu politycznego. Żydzi mieli ograniczoną możliwość wstępowania do Akademii Wojskowej, Szkoły Oficerów Rezerwy oraz nie uzyskiwali wyższych stopni oficerskich ${ }^{41}$. Jednym z powodów ograniczonych możliwości Żydów był też kształt egzaminów wstępnych do Akademii, gdzie należało wykazać się znajomością języków bułgarskiego i rosyjskiego, jak również posiadaniem wiedzy z zakresu Pisma Świętego ${ }^{42}$. Nie znaczy to bynajmniej, że nie było Żydów studiujących w Akademii Wojskowej w Bułgarii. W 1889 roku, po trzech latach nauki, uczelnię w stopniu podporucznika ukończył pierwszy przedstawiciel tej mniejszości, Rachamim Moszon Garti ${ }^{43}$.

Zjednoczenie Bułgarii i Rumelii Wschodniej we wrześniu 1885 roku i będąca jego konsekwencją wojna bułgarsko-serbska spotkały się z pozytywnym oddźwiękiem ze strony rodzimych Żydów, niezależnie od powtarzających się okresowo aktów o cha-

39 Ж. Назърска, Българската държава и нейните малиинства..., s. 183.

40 Й. Илел, Българските евреи във войните на България (1885, 1912-1913 и 1915-1918), „Годишник ОКПОЕ”, 1987, t. 22, s. 147.

41 V. Paounovski, The Anti-Jewish legislation in Bulgaria during the Second World War, w: V. Paounovski, J. Ilel, The Jews in Bulgaria between the Holocaust and the Rescue, Sofia 2000, s. 71.

42 Ж. Назърска, Българската държава и нейните малиинства..., s. 186.

43 W późniejszym okresie Garti wziął udział w pierwszej wojnie bałkańskiej, wojnie międzysojuszniczej oraz w I wojnie światowej. Po jej zakończeniu został przeniesiony w stan spoczynku w stopniu pułkownika. Zob. J. Ilel, The Bulgarian Jews - the factor in the struggle for their own survival from the Holocaust. Why did the Bulgarians save the Jews in Bulgaria?, w: V. Paounovski, J. Ilel, op. cit., s. 179-180. 
rakterze dyskryminacyjnym. Niektórzy autorzy obliczają, że liczba zmobilizowanych Żydów wyniosła w sumie 720 osób $^{44}$ (w momencie wybuchu wojny armia bułgarska liczyła 99507 żołnierzy wszystkich rodzajów wojsk ${ }^{45}$ ), nie licząc kolejnych ochotników napływających do armii, przede wszystkim z Ruse i Warny. Z ochotników żydowskich sformowano oddział pod dowództwem Dawida Mizrachiego, który wziął udział w głównych bitwach wojny pod Sliwnicą i Pirotem, za co później otrzymał wyrazy uznania ze strony monarchy. Spośród wyróżniających się w działaniach wojennych Żydów należy wskazać również Leona Aseowa z Dupnicy, Awrama Bechmoarama z Ruse, Awrama Sabitajewa z Widynia oraz Jako Moszewa z Łomu ${ }^{46}$. Ogółem w działaniach wojennych śmierć poniósł tylko jeden żołnierz pochodzenia żydowskiego. Był nim Jako Mordechaj z Breznika, który zginął 6 listopada 1885 roku $^{47}$.

Rodzima mniejszość uczestniczyła także w działaniach na zapleczu frontu, biorąc udział w budowie umocnień polowych na zachód od Sofii. Według niektórych relacji to właśnie ta grupa Żydów miała najbardziej obawiać się ewentualnych działań zbrojnych, a strach budziła u nich już sama rozmowa na ten temat ${ }^{48}$. Także inni Żydzi mieszkający w niewielkiej odległości od granicy z Serbią obawiali się konsekwencji działań militarnych. W tym kontekście szczególnie zagrożona była wspólnota z Widynia, która w całości ewakuowała się do Kalafatu na terytorium Rumunii, gdzie pomocy udzielili im miejscowi współwyznawcy 49 .

W czasie wojny stolica Bułgarii stała się głównym punktem, do którego trafiali ranni. Społeczność żydowska w mieście ze swoich środków zorganizowała dla nich szpital polowy, w którym personel medyczny stanowili przedstawiciele tej grupy, m.in. dr Samuel Lewi, Mordechaj Chaim, Samuel Solomon, Nissim Arie oraz Nissim Tadżer. Jako pomoc pielęgniarska służyła również grupa około 40 kobiet żydowskich. W sumie przez szpital przewinęło się 135 rannych lub chorych żołnierzy ${ }^{50}$. W dowód uznania dla poświęcenia społeczności placówkę odwiedziło wielu przedstawicieli władz, na czele z monarchą księciem Aleksandrem Battenbergiem, który nadał odznaczenia przebywającym tam czterem żołnierzom pochodzenia żydowskiego ${ }^{51}$.

Wszystkie przytoczone wyżej fakty pozwalają na wysunięcie wniosku, że Żydzi, pomimo okresowych utrudnień stwarzanych przez niektóre rządy, pozytywnie odnieśli się do jednego z celów narodowych Bułgarów, jakim było zjednoczenie Księstwa i Rumelii Wschodniej. Będąca efektem scalenia tych prowincji wojna z Serbią i ich

44 Й. Илел, Българските евреи във войните..., s. 148.

45 П. Сантурджиев, Доброволичте в сърбско-българската война 1885 г., София 1929, s. 5.

46 Й. Илел, Българските евреи във войните..., s. 149. Szerzej na temat udziału oficerów żydowskich w wojnach toczonych przez Bułgarię w latach 1885-1918 zob. Й. Илел, Евреи-офицери във войните на България 1885, 1912-1913, 1915-1918, „Годишник ОКПОЕ”, 2004, t. 31, s. 103-125.

47 Изиълнен отечествен дълг. Въспометалетен сборник посветен на българските евреи участвували във войните, София 1939, s. LVIII.

48 C. Roy, Souvenirs politiques et militaires de Bulgarie. Deux revolutions. La guerre serbo-bulgare, Paris 1887 , s. 86.

49 „Bulletin de l'Alliance Israélite Universelle”, 1885-1886, nr 10, s. 22.

${ }^{50}$ И. Шипчанов, op. cit., s. 58-59.

51 „Bulletin de l'Alliance Israélite Universelle”, 1885-1886, nr 10, s. 23. 
czynny udział w walkach i działania na zapleczu frontu wskazują, że czuli się oni związani z krajem swojego zamieszkania, wyrażając gotowość oddania życia w jego obronie. To nastawienie nie zmieniło się w kolejnych wojnach toczonych przez Bułgarię Żydzi bułgarscy uczestniczyli w wojnach bałkańskich oraz w I wojnie światowej, poświęcając w obronie swojej przybranej ojczyzny w sumie 952 ofiary śmiertelne ${ }^{52}$.

Mniejszości żydowskiej w Księstwie Bułgarii nie ominął również jeden z najważniejszych procesów, jakie były udziałem całej wspólnoty pod koniec XIX wieku, a mianowicie pojawienie się idei odtworzenia ich siedziby narodowej w Palestynie. Co prawda zorganizowany ruch syjonistyczny pojawił się w Bułgarii dopiero w 1895 roku $^{53}$, jednak jak wskazują niektórzy, jeszcze w 1881 roku Izaak Dawidowicz Bali, nauczyciel ladino z Ruse, głosił konieczność zbudowania państwa żydowskiego na dwóch brzegach Jordanu ${ }^{54}$. Rok później z podobną tezą wystąpił nauczyciel z Widynia Baruh Mitrani, który stwierdził, że Żydzi powinni powrócić do opisanego w Torze Izraela. W późniejszych latach Mitrani podjął się wydawania pisma „Карми” („Karmi”), pierwszego syjonistycznego tytułu prasowego na ziemiach bułgarskich ${ }^{55}$. Wskazane wyżej wypowiedzi sugerują, że wspólnota Żydów bułgarskich była dobrze poinformowana o aktualnych prądach ideowych i dyskusjach toczących się w diasporach żyjących w innych krajach europejskich. Trudno jednak w tym miejscu stwierdzić jednoznacznie, w którym momencie koncepcja budowy siedziby narodowej w Palestynie pojawiła się w Bułgarii oraz kto odegrał główną rolę w jej zaszczepieniu na terytorium tego państwa.

Odnowiona po wojnie rosyjsko-tureckiej Bułgaria od początku istnienia skupiła się na realizacji swoich celów narodowych, jakimi była budowa jednolitego etnicznie i zjednoczonego terytorialnie, ze wszystkich ziem uznawanych za bułgarskie, państwa. Skutkowało to niekiedy niewypełnianiem przez władze postanowień kongresu berlińskiego i zasad zapisanych w konstytucji tyrnowskiej w stosunku do mniejszości, przede wszystkim wobec najliczniej zamieszkującej Księstwo Bułgarii mniejszości tureckiej. To działania wobec tej właśnie grupy były lepiej zorganizowane i miały bardziej widoczny charakter. $Z$ szykanami i ograniczeniami w różnych dziedzinach spotykali się również Żydzi, szczególnie w okresach, kiedy na czele rządu stali antysemicko nastawieni politycy, w tym przede wszystkim wspomniani wyżej gen. Leonid Sobolew i Petko Karawełow. To w czasie funkcjonowania gabinetu Sobolewa po raz pierwszy doszło do usankcjonowania działań antyżydowskich na szczeblu państwa. Niemniej, wydaje się, że sytuacja, w jakiej znalazła się mniejszość żydowska w Bułgarii nie była zła, jeśli wziąć pod uwagę chociażby stopień antysemityzmu w sąsiedniej Rumunii czy też w Rosji. Rumunia jeszcze w uchwalonej w 1866 roku

\footnotetext{
52 Szczegółowa lista poległych została zestawiona w cytowanej wyżej książce: Изиълнен отечествен дълг..., s. I-LXI.

${ }^{53} \mathrm{Na}$ ten rok początek zorganizowanego ruchu syjonistycznego w Bułgarii datuje Szlomo Szealtiel. Zob. Ш. Шеалтиел, Ционизмът в България. Особености на едно лидерско движение, София 2012, s. 27.

54 Й. Ково, Евреите от Русе - между изтока и запада, „Мабат”, 2006, nr 2, s. 90.

55 Ф. Декало, Началото на ционистическия печат в България (Проблеми и теми в 5 водещи ичонистически издания в България в края на ХІХ и началото на ХХ век), „Мабат”, 2005, nr 1, s. 74.
} 
konstytucji odebrała prawa polityczne niechrześcijanom, w obu krajach dochodziło również do cyklicznie powtarzających się pogromów ludności żydowskiej, o których informacje przenikały na ziemie bułgarskie dzięki prasie ${ }^{56}$. Szczegółowa analiza tych kwestii wykracza jednak poza ramy zarysowane w tytule artykułu.

Liczba Żydów mieszkujących w Bułgarii ulegała powolnemu, acz ciągłemu wzrostowi, którzy utrzymał się aż do wybuchu II wojny światowej, co wskazuje, że rzadko decydowali się oni na emigrację, także w okresie dominacji ideologii syjonistycznej wśród lokalnej wspólnoty w Bułgarii. Przedstawiciele tej grupy pozytywnie odebrali też zjednoczenie Księstwa Bułgarii z Rumelią Wschodnią, biorąc udział w walkach i działaniach na zapleczu frontu w czasie konfliktu serbsko-bułgarskiego. O ich przywiązaniu do kraju zamieszkania świadczyło też zaangażowanie w kolejnych wojnach.

Jak wskazują niektórzy badacze, bardziej tolerancyjną politykę w stosunku do mniejszości prowadzono w sąsiedniej Rumelii Wschodniej, wchodzącej formalnie w skład Imperium Osmańskiego. Negatywne nastawienie do grup odrębnych etnicznie i religijnie w Księstwie Bułgarii przez dominujących prawosławnych Bułgarów w latach 1879-1885 doprowadziło w konsekwencji również do pewnego zdeformowania polityki państwa wobec mniejszości w kolejnym okresie, już po zjednoczeniu $\mathrm{kraju}^{57}$. W stosunku do mniejszości żydowskiej skutkowało to między innymi wzrostem nastrojów antysemickich i powtarzających się okresowo oskarżeń o rytualne zabójstwa dzieci, w czym celowały przede wszystkim antyżydowskie tytuły prasowe. Doprowadziło to nawet do nacisku na parlament bułgarski pod koniec XIX wieku, aby przyjął ustawodawstwo antysemickie, ostatecznie jednak inicjatywa ta zakończyła się kompletnym fiaskiem ${ }^{58}$.

\section{BIBLIOGRAFIA:}

Ботушаров Христо, Софийските евреи през 1878-1885 2., „Годишник ОКПОЕ”, 1988, t. 23, s. 99-118.

Генов Румен, Дизраели, еврейството и антисемитизъм в България, http://dialogueeurope.org/uploads/JewsCol/Panel101.pdf [dostęp: 03. 02. 2016], s. 24-34.

Гешева Йорданка, Режимът на пълномощията - своеобразна форма на управление на държавата (1881-1883 г.), w: Eadem, Консерваторите, партията, личностите и изграждане на българската държава 1879-1886 г., изд. къща Дио Мира, София 2013, s. 231-247.

Декало Феня, Началото на ционистическия печат в България (Проблеми и теми в 5 водещчи ичонистически издания в България в края на XIX и началото на ХХ век), „Мабат”, 2005, nr 1, s. $74-81$.

56 S. Marton, Designing citizenship. The "Jewish question" in the debates of the Romanian parliament (1866-1869), "Quest. Issues in Contemporary Jewish History. Journal of Fondazione CDEC" 2012, no. 3, s. 35-55. Na temat pogromów ludności żydowskiej w Rosji zob. M. Aronson, Troubled waters. The origins of the 1881 Anti-Jewish pogroms in Russia, Pittsburgh 1990.

57 Ж. Назърска, Българската държава и нейните малиинства..., s. 227-228.

${ }^{58}$ V. Kulenska, The Antisemitic Press in Bulgaria at the End of the 19th Century, "Quest. Issues in Contemporary Jewish History. Journal of Fondazione CDEC", 2012, nr 3, s. 72-85. 
Ешкенази Ели, Освобождението на България и българските евреи (Създаването на равинския инcmuтуm), „Годишник ОКПОЕ”, 1979, t. 14, s. 27-32.

Изиълнен отечествен дълг. Въспометалетен сборник посветен на българските евреи участвували във войните, Печатница Т. Драгиевъ и синъ, София 1939.

Илел Йосиф, Българските евреи във войните на България (1885, 1912-1913 и 1915-1918), „Годишник ОКПОЕ”, 1987, t. 22, s. 139-206.

Илел Йосиф, Евреи-офицери във войните на България 1885, 1912-1913, 1915-1918, „Годишник ОКПОЕ", 2004, t. 31, s. 103-125.

Илиев Атанас, Старозагорский окръг в народоикономическо отночение, Стара Загора 1885. Cуt. za: Евреите по българските земи. Анотирана библиография, съст. Жак Ескенази, Алфред Криспин, изд. IMIR, София 2002, s. 236.

Калев Аструк, Данни относно демографското положение на българските евреи (1887-1940), „Годишник ОКПОЕ”, 1981, t. 16, s. 99-112.

Ково Йосеф, Евреите от Русе - между изтока и запада, „Мабат”, 2006, nr 2, s. 89-93.

Коен Давид, Българските евреи по време на Освобождението от турско владичество, w: Idem, Евреите в България (1878-1949). Студии, изд. Факел - Леонидови, София 2008, s. 12-25.

Коен Давид, Сефардските общини в България (1878-1944 г.), w: Idem, Евреите в България (18781949). Студии, изд. Факел - Леонидови, София 2008, s. 56-104.

Кьосо Алберт, „Макаби” и еврейският спорт в България, „Вестник на вестниците”, 5 април 1936, бр. 50 , s. 30 .

Манафова Райна, Просветно и културно приобщаване на българските евреи от освобождението до първата световна война, w: Проучвания за еврейското население в българските земи XV- XX век, изд. Българската Академия на Науките, София 1980, s. 53-75.

Назърска Жоржета, Българската държава и нейните малиинства 1879-1885, изд. ЛИК, София 1999.

Назърска Жоржета, Етническите и религиозните малцинства в българския парламент (18791885), „Исторически преглед”, 1999, nr 1-2, s. 3-22.

Неделева Петя, Място и роля на еврейската общност в българските земи (от османско владичество до 30-те години на ХХ в.), „Юридическо списание на НБУ”, 2013, nr 2, s. 33-57.

Сантурджиев Панайот, Доброволиите в сърбско-българската война 1885 г., Печатница Б.А. Кожухаров, София 1929.

Ташев Ташо, Министрите на България 1879-1999, изд. Българската Академия на Науките, София 1999.

Цвятков Николай, Просветното дело сред българските евреи в края на XIX и началото на XX век, „Годишник ОКПОЕ”, 1980, t. 15, s. 113-126.

Шеалтиел Шломо, Ционизмът в България. Особености на едно лидерско движение, изд. ОРБЕЛ, София 2012.

Шипчанов Иван, Съединението на България през 1885 г. и българските евреи, „Годишник ОКПОЕ”, 1985 , t. 20, s. 45-64.

Aronson Michael, Troubled waters. The origins of the 1881 Anti-Jewish pogroms in Russia, University of Pittsburgh Press, Pittsburgh 1990.

A Sephardi life in Southeastern Europe. The autobiography and journal of Gabriel Arié, 1863-1939, red. Esther Benbassa, Aron Rodrigue, University of Washington Press, Seattle-London 1998.

Bigart Jacques, The Alliance Israélite Universelle, “American Jewish Year Book”, 1901, nr 2, s. 45-66. „Bulletin de l'Alliance Israélite Universelle”, 1885-1886, nr 10, s. 22-23.

Documents diplomatiques. Affaires d'Orient. Congrès de Berlin 1878, Imprimerie Nationale, Paris 1878.

Erdic Jean, En Bulgarie et en Roumélie, Mai-Juin 1884, Imprimerie Emile Colin à Saint-Germain, Paris 1884 .

Fabrikant Adolf, The Ashkenazic Presence in Bulgaria, Part III. The Contribution of The Ashkenazim to The General Life of The Country, "Annual”, 1995, t. 28, s. 77-119.

Gelber Nathan Michael, Jewish life in Bulgaria, ,Jewish Social Studies”, 1946, t. 8, nr 2, s. 103-126. 
Ilel Josif, The Bulgarian Jews - the factor in the struggle for their own survival from the Holocaust. Why did the Bulgarians save the Jews in Bulgaria?, w: Vladimir Paounovski, Josif Ilel, The Jews in Bulgaria between the Holocaust and the Rescue, Adasa-Press, Sofia 2000, s. 163-200.

Kulenska Victoria, The Antisemitic Press in Bulgaria at the End of the $19^{\text {th }}$ Century, "Quest. Issues in Contemporary Jewish History. Journal of Fondazione CDEC", 2012, nr 3, s. 72-85.

Marton Silvia, Designing citizenship. The "Jewish question" in the debates of the Romanian parliament (1866-1869), "Quest. Issues in Contemporary Jewish History. Journal of Fondazione CDEC" 2012, no. 3, s. 35-55.

Nedkov Tzvetolin, Peter Gabe 1857-1927. 110 Years Since His Settlement in Bulgaria, “Annual”, 1995, t. 28 , s. 226-232.

Omer Danielle, Le français, l'allemand, l'anglais: l'impossible alliance? L'example du réseau scolaire de l'AIU (1860-1913), http://hal.univ-nantes.fr/hal-01112097/document, s. 1-28.

Paounovski Vladimir, The Anti-Jewish legislation in Bulgaria during the Second World War, w: Vladimir Paounovski, Josif Ilel, The Jews in Bulgaria between the Holocaust and the Rescue, Adasa-Press, Sofia 2000, s. 67-120.

Puchner Walter, The Theatre in South-East Europe in the Wake of Nationalism, w: Tendances actuelles de la littérature compareé dans le Sud-est de l'Europe, red. Anna Tabaki, INR/NHRF, Athènes 2007, s. 66-122.

Roy Christophe, Souvenirs politiques et militaires de Bulgarie. Deux revolutions. La guerre serbo-bulgare, Imprimerie Charles Bayle, Paris 1887.

Rusin Bartłomiej, Konstytucja tyrnowska z 1879 roku - historia, ustrój, język, w: Historyczna i ponowoczesna tożsamość Stowian, red. J. Zatorska, A. Skoczylas, T. Ciesielski, Uniwersytet Łódzki, Łódź 2012, s. 73-95.

Rusin Bartłomiej, Prawa, wolności i obowiązki człowieka i obywatela w świetle konstytucji tyrnowskiej z 1879 r., „Meritum. Rocznik Koła Naukowego Historyków-Doktorantów UWM w Olsztynie”, 2012, t. IV, s. 93-104.

Rusin Bartłomiej, Pogromy Żydów na ziemiach bułgarskich Imperium Osmańskiego w czasie wojny rosyjsko-tureckiej 1877-1878, „Studia z Dziejów Rosji i Europy Środkowo-Wschodniej” [w druku].

Samuelson James, Bulgaria. Past And Present, Trubner \& Co., London 1888.

Üre Pinar, Immediate effects of the 1877-1878 Russo-Ottoman War on the Muslims of Bulgaria, "History Studies", 2013, nr 13, s. 153-170. 
